\title{
Using leaf micromorphology as a tool for identifying tree seedlings: a proof of concept using a fast technique
}

\author{
Bruna Panosso \\ Guilherme Bordignon Ceolin * \\ Universidade Federal de Santa Maria, Campus Frederico Westphalen \\ Linha 7 de Setembro, BR 386 Km 40, CEP 98.400-000, Frederico Westphalen - RS, Brasil \\ * Autor para correspondência \\ ceolingb@gmail.com
}

Submetido em 03/03/2020

Aceito para publicação em 10/08/2020

\section{Resumo}

Micro-morfologia foliar como ferramenta de identificação de plântulas: uma prova de conceito utilizando-se uma técnica rápida. A identificação eficaz de espécies vegetais é fundamental para uma melhor compreensão da regeneração natural. Contudo, métodos taxonômicos clássicos dependem de estruturas reprodutivas, geralmente ausentes em indivíduos jovens. Para superar essa dificuldade, várias abordagens podem ser aplicadas, sendo um bom exemplo a anatomia externa da epiderme foliar (doravante micro-morfologia). Portanto, nosso objetivo foi testar, através de uma técnica rápida, se a micro-morfologia da epiderme foliar pode fornecer caracteres distintivos suficientes para a identificação de plântulas de espécies arbóreas em geral. Escolhemos seis espécies comuns da Floresta Estacional do Sul do Brasil para realizar uma prova de conceito, sendo coletadas de duas a quatro folhas de plântulas selecionadas aleatoriamente (cinco repetições/espécies). Em seguida, a epiderme foliar foi pressionada em uma lâmina de microscopia com adesivo instantâneo, cuja imagem impressa foi analisada em busca de características diagnósticas. As análises mostraram que várias características anatômicas da superfície foliar são suficientemente distintas para permitir uma identificação correta das espécies, como o formato das paredes anticlinais das células epidérmicas, o formato dos estômatos e a presença/ausência de glândulas e cutícula. Portanto, a conclusão deste estudo é que a micro-morfologia epidérmica foliar pode ser usada como fonte de características diagnósticas para identificar corretamente as plântulas de espécies florestais.

Palavras-chave: Epiderme; Impressão foliar; Regeneração; Resiliência

\section{Abstract}

Effective identification of plant species is fundamental to better understand natural regeneration. However, classical taxonomic methods largely rely on reproductive structures, which are frequently absent in juvenile individuals. To overcome this difficulty, several approaches can be applied, of which a good example is the external anatomy (hereafter micromorphology) of the leaf epidermis. Therefore, the aim of this study was to test, using a fast technique, if leaf micromorphology can provide suitable distinctive characters to identify seedlings of tree species. We chose six common species from seasonal forest in southern Brazil for our tests and collected two to four leaves from randomly selected seedlings (five replicates/species). Then, we printed the leaf epidermis on a microscope slide with instant adhesive and analyzed the print for diagnostic features. Our analyses showed that several anatomical characteristics of the leaf surface are distinct enough to allow for 
correct species identification, such as the shape of the anticlinal walls of epidermal cells, shape of stomata, and presence/absence of glands and a cuticle. Hence, the conclusion of this study is that leaf epidermal anatomy can be used as a source of diagnostic characteristics to correctly identify seedlings of forest species.

Key words: Epidermal printing; Leaf surface; Regeneration; Resilience

\section{Introduction}

Natural regeneration studies are essential for correctly diagnosing forest quality and provide parameters, such as growth rate of new individuals and their increase or decrease in biomass. These parameters are frequently used to support the proposal of better strategies for forest management and preservation (CARVALHO, 1982; GAMA et al., 2003). In order to satisfactorily achieve their goals, studies focusing on natural regeneration need to identify which plant species are growing in the understory of a given forest. Consequently, botanical identification must be as accurate as possible.

Botanical taxonomy generally relies on the collection of flowers and/or fruits from adult plants. Alternatively, in some cases, wood anatomy can be used (RODERJAN, 1983), as well as the type of crown or the appearance of stems and bark (JIMENEZ-SAA, 1969). However, these characteristics are primarily applied to adult individuals, which is a drawback to seedling identification. Juvenile specimens lack reproductive structures commonly used to identify adult individuals, as well as a sufficiently developed crown and wood. Fortunately, several alternative identification techniques can be used to solve this impasse, notably leaf anatomy, regardless of the stage of plant development.

As affirmed by Guantay and Terán (1995), anatomical and morphological studies can be a source of new taxonomic characters. In fact, a brief review of the literature promptly demonstrates the importance of this taxonomic tool, since papers have dealt with this topic for a long time. For example, Esau (1960), Fahn (1982) and Hickey and King (2000) state that leaves are the most labile vegetative plant structures in terms of morphological and anatomical characteristics because they have to cope directly with numerous conditions of their habitat. Although this variable nature, leaf anatomy has largely been used to identify species of several botanical families (ANDERSON; CREECH, 1975; PRYCHID; RUDALL, 1999; ALVES et al., 2002; BIERAS; SAJO, 2004; CEOLIN et al., 2009; WOODENBERG et al., 2019). However, to date, only one study has been carried out that had the goal of identifying seedlings using this method (CEOLIN et al., 2007) and it dealt with only two species.

Thus, in this paper, we evaluate using the micromorphology of the leaf surface as a tool to help researchers identify plants at their juvenile stage (seedlings). Additionally, we also looked for microscopic morphological characters that could be potentially used to identify other plant species.

\section{Material and Methods}

We chose six common species native to seasonal forest in southern Brazil as our sample universe for our tests (proof of concept): Pilocarpus pennatifolius Lem. (Rutaceae), Eugenia rostrifolia D. Legrand (Myrtaceae), Chrysophyllum marginatum Hook. \& Arn. (Sapotaceae), Cupania vernalis Cambess (Sapindaceae), Prunus myrtifolia Chodat \& Hassl. (Rosaceae), and Cordia americana (L.) Gottshling \& J. E. Mill. (Cordiaceae). We randomly selected several seedlings of each species ( $<1 \mathrm{~m}$ tall), making sure to avoid leaves damaged by herbivores and/or pathogens (five replications/species). We made the collections in a private forest patch in the city of Palmitinho (all adults and some seedlings; $27^{\circ} 20^{\prime} \mathrm{S}$; $53^{\circ} 33^{\prime} \mathrm{W}$ ) and in forest nurseries in the city of Frederico Westphalen (most seedlings; 27²3'S; $\left.53^{\circ} 25^{\prime} \mathrm{W}\right)$.

Since the principle of a good taxonomic technique is an optimal combination of practicality, speed and low cost, the challenge is to find a method that more or less uniformly merges these three factors. This challenge 
is especially difficult when it comes to leaf anatomy, since widely used methods involve several steps, such as dehydration and staining the studied material (ZHONG et al., 2018). An alternative method was tested and proposed by Segatto et al. (2004), which takes advantage of the fact that the anatomical structures of a leaf epidermis can be transferred to a microscope slide by printing them using a fast-drying adhesive. When well executed, this technique allows the visualization of epidermal cells, shape of the veins, stomata, and trichomes, notably their shape, arrangement, and distribution on the leaf surface. The fidelity of the impression guarantees the minimum necessary precision for the identification of several morphological patterns used in species discrimination. Moreover, this technique is affordable, saves time, and has already been tested in anatomic studies applied to the taxonomy of other species (CEOLIN et al., 2007). The leaf printing technique in our study consisted of using universal, instant adhesive cyanoacrylate ester to make the microscope slides. First, we used a razor blade to separate the middle part of each leaf selected for printing. For species with compound leaves $(C$. vernalis and $P$. pennatifolius) we always chose the terminal leaflet for the test. Subsequently, we placed one drop of adhesive on the microscope slide and pressed each side of the leaf epidermis (adaxial and abaxial) into the adhesive for about thirty seconds. After this, we removed the leaf blade, leaving the epidermal print on the slide. We photographed the slides under a light microscope and analyzed the pictures.

We analyzed the following features to differentiate the species: shape of the anticlinal walls of the epidermal cells, shape of the stomata cells, visibility of the stomata using optical microscopy, elevation of the stomata in relation to the level of adjacent cells, presence of glands and presence of a cuticle.

In addition, to cross-check the seedling identification, we also made some slides with adult individuals of the same species and compared their leaf anatomy with that of the seedlings. We did this to determine if there are changes in the anatomical structures during plant development.

\section{Results}

The results of our anatomical analyses showed that several characteristics on the leaf surface have taxonomic value and can be used to identify the different plant species, even at the juvenile stage. In addition, the anatomical comparisons also showed that most of the differences found between seedlings and adults are quantitative (e.g., size and number of structures) rather than qualitative (e.g., shape) traits. Therefore, these results support the assumption that the leaf anatomy of adult individuals of known identity can be securely used to identify seedlings of unknown species by comparison. Accordingly, our paper represents a methodological advance compared to the pioneering work of Ceolin et al. (2007), which used the same technique to discriminate the seedlings of two palm species, but without making a comparison among adult individuals.

The anatomical characteristics that allow the identification of species are summarized in Table 1 and described below.

Pilocarpus pennatifolius: shape of the anticlinal walls straight, stomata well visible, cells with circular shape, cuticle and glands present (Figure 1).

TABLE 1: Leaf epidermis traits used to identify the tree seedlings species.

\begin{tabular}{|c|c|c|c|c|c|c|}
\hline Character/Species & $\begin{array}{c}P . \\
\text { pennatifolius }\end{array}$ & E. rostrifolia & $\begin{array}{c}C . \\
\text { marginatum }\end{array}$ & $\begin{array}{c}C . \\
\text { vernalis }\end{array}$ & $\begin{array}{c}P . \\
\text { myrtifolia }\end{array}$ & C. americana \\
\hline Shape of anticlinal cell wall & straight & straight & sinuous & sinuous & sinuous & straight \\
\hline Shape of stomata guard-cells & round & elliptical & elliptical & not evident & elliptical & elliptical \\
\hline Stomata level* & same level & same level & same level & not evident & higher level & higher level \\
\hline Glands & present & present & absent & absent & absent & absent \\
\hline Cuticle & present & present & present & absent & present & absent \\
\hline
\end{tabular}

* When compared to the level of the surrounding epidermal cells. 
FIGURE 1: Pilocarpus pennatifolius. Leaf adaxial surface. A. Young individual. B. Adult individual. Leaf abaxial surface. C. Young individual. D. Adult individual. Scale bar: $40 \mu \mathrm{m}$. Arrow indicates translucent gland.

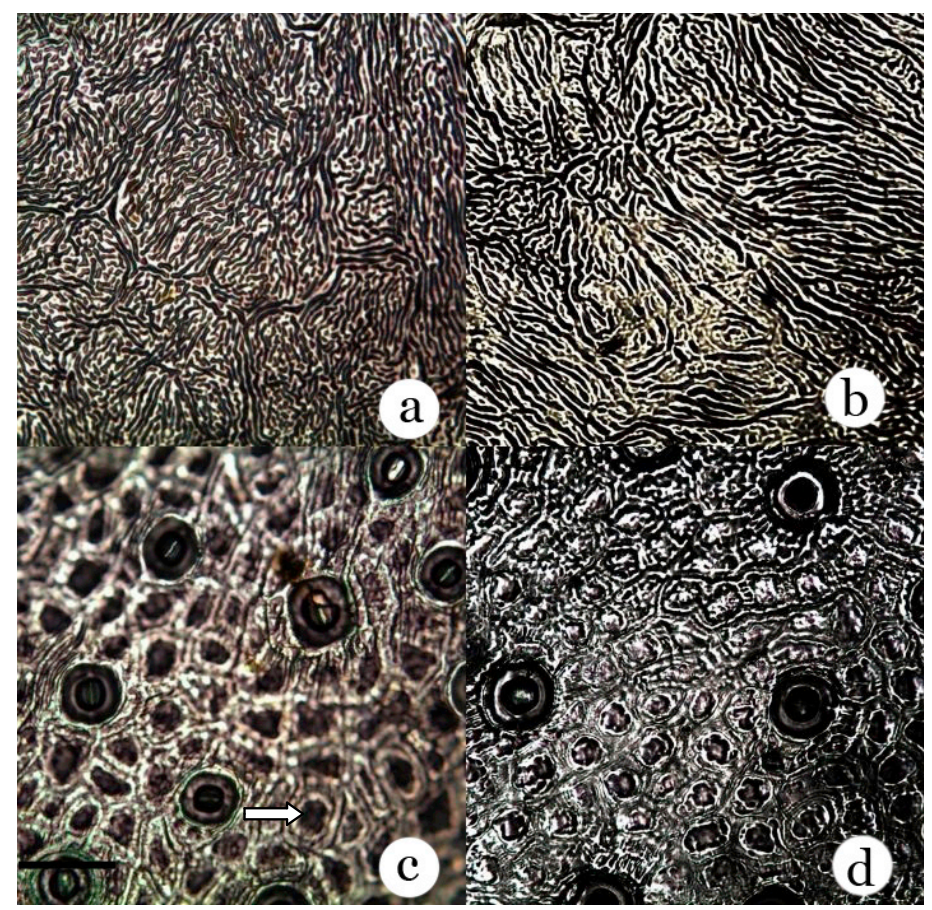

Eugenia rostrifolia: shape of the anticlinal walls straight, shape of the stomata guard cells elliptical, stomata well visible, glands and cuticles present (Figure 2).
Chrysophyllum marginatum: shape of the anticlinal walls slightly sinuous, shape of the stomata guard cells elliptical, stomata well visible, no glands or cuticle (Figure 3).

FIGURE 2: Eugenia rostrifolia. Leaf adaxial surface. A. Young individual. B. Adult individual. Leaf abaxial surface. C. Young individual (scale bar: $30 \mu \mathrm{m}$ ). D. Adult individual.

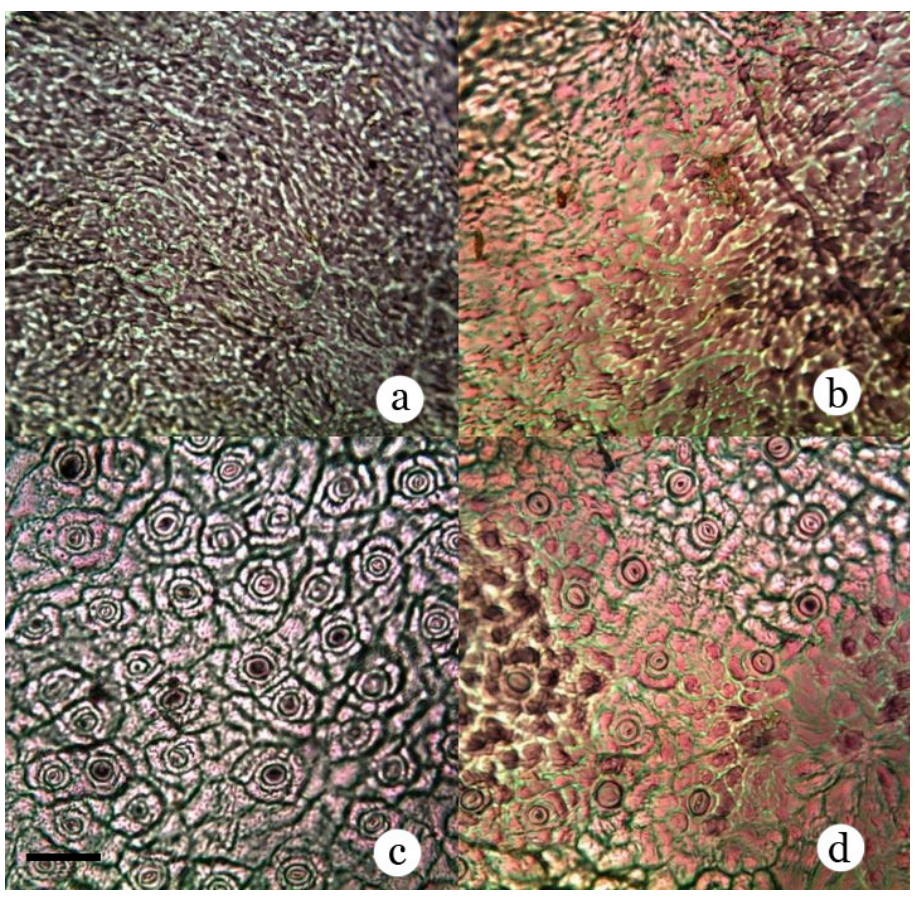


FIGURE 3: Chrysophyllum marginatum. Leaf adaxial surface. A. Young individual. B. Adult individual. Leaf abaxial surface. C. Young individual. D. Adult individual. Scale bar: $30 \mu \mathrm{m}$

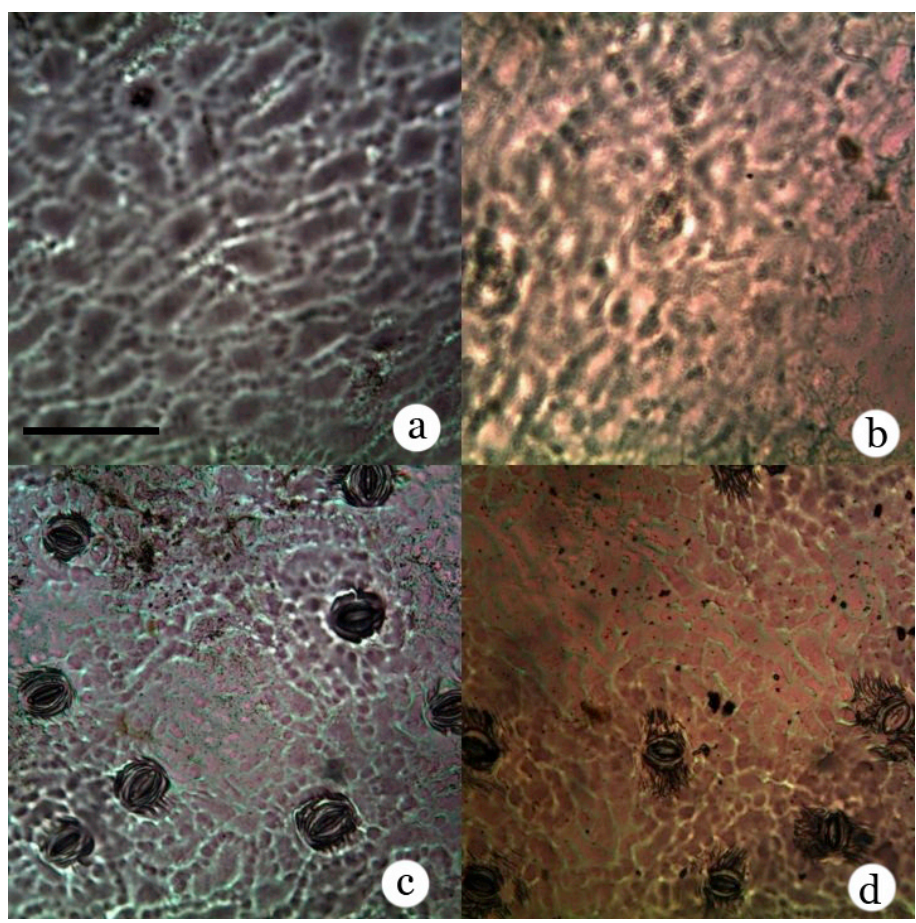

Cupania vernalis: shape of the anticlinal walls slightly sinuous, stomata not remarkably evident, no glands or cuticles (Figure 4).
Cordia americana: shape of the anticlinal walls straight, shape of the stomata guard cells elliptical, stomata well visible, no glands or cuticle (Figure 5).

FIGURE 4: Cupania vernalis. Leaf adaxial surface. A. Young individual. B. Adult individual. Leaf abaxial surface. C. Young individual (scale bar: $30 \mu \mathrm{m})$. D. Adult individual.

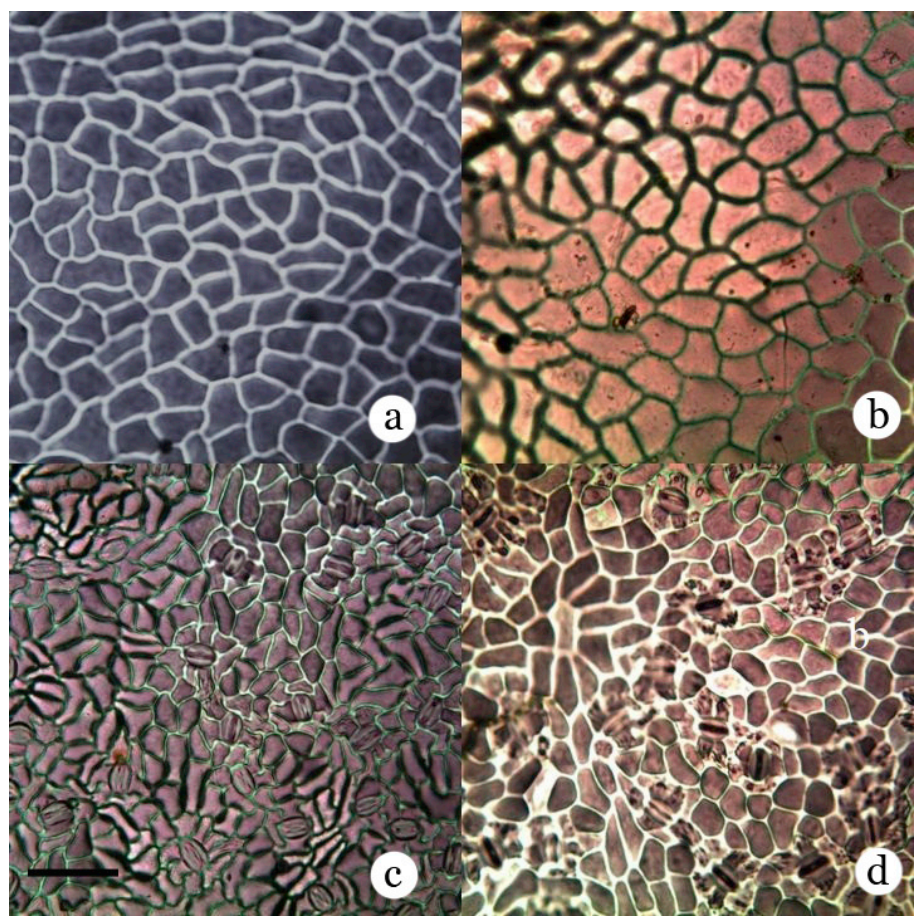


FIGURE 5: Cordia americana. Leaf adaxial surface. A. Young individual. B. Adult individual. Leaf abaxial surface. C. Young individual (scale bar: $20 \mu \mathrm{m}$ ). D. Adult individual.

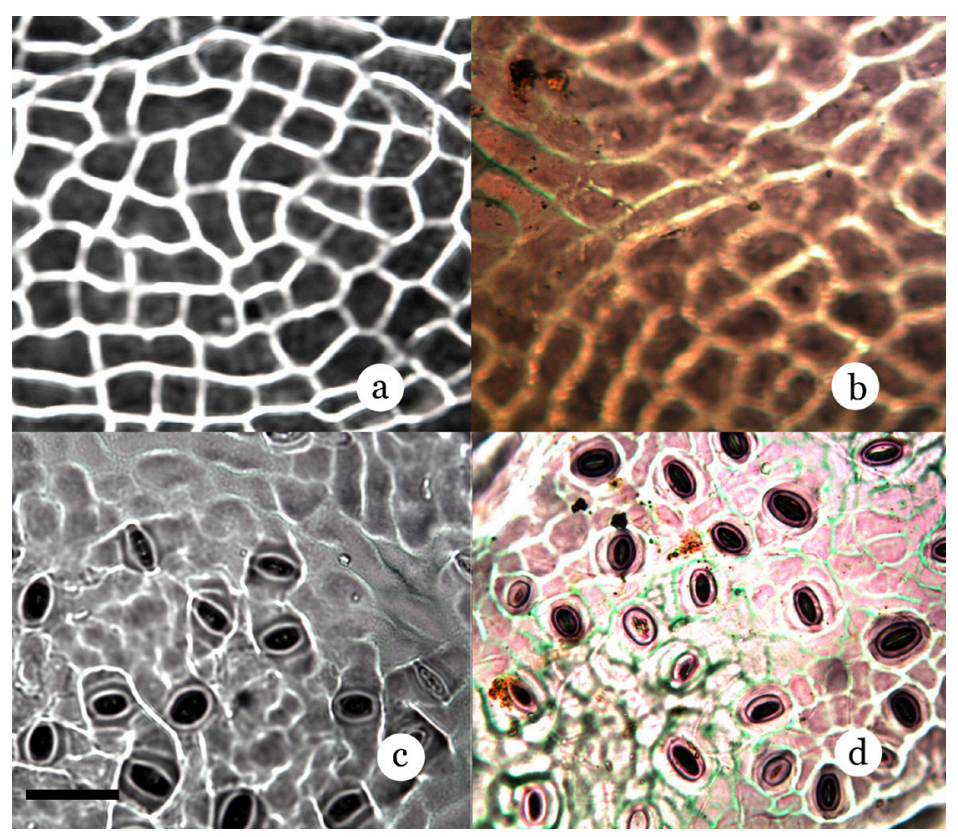

Prunus myrtifolia: shape of the anticlinal walls slightly sinuous, shape of the stomata guard cells elliptical, stomata well visible and placed at a different level relative to surrounding cells, no glands, cuticle present (Figure 6).

FIGURE 6: Prunus myrtifolia. Leaf adaxial surface. A. Young individual. B. Adult individual. Leaf abaxial surface. C. Young individual. D. Adult individual. Scale bar: $25 \mu \mathrm{m}$.

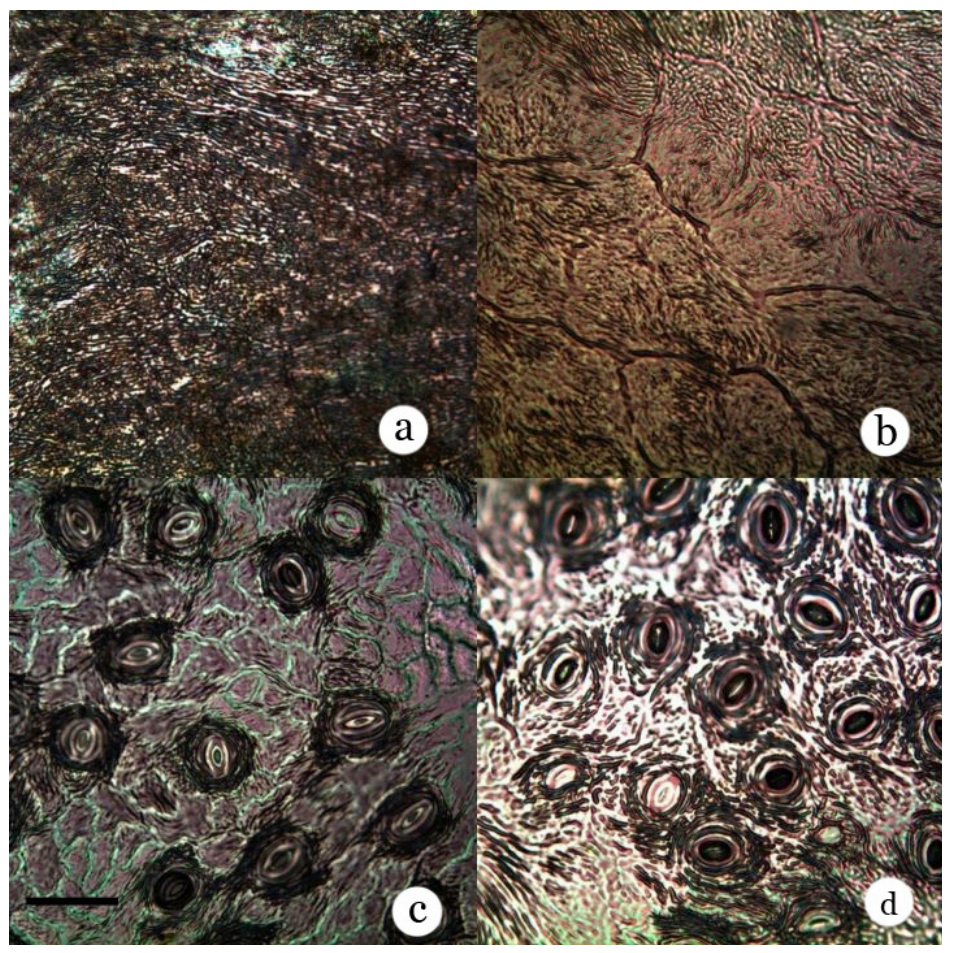




\section{Discussion}

Our analyses showed that there are several morphological attributes on the leaf epidermal surface that can be used to safely distinguish different species of seedlings. In addition, the glue printing technique proved to be feasible because it was fast, quite inexpensive, efficient, and provided a clear view of the epidermal structures. Besides this, the slides are semipermanent and long-lasting since they can remain at room temperature for a long time. A similar observation was made by Segatto et al. (2004), whose work tested several techniques and concluded that glue printing is the best method to obtain this type of microscope slide.

Regarding the anatomical descriptors we proposed to identify the species, several of them have already been proposed in previous studies because their shapes are quite stable within the species, but variable among species, at least qualitatively. Indeed, most traits observed in plants are influenced by climatic factors. However, climatic variables generally determine the way in which quantitative traits, such as measurements and counts, will vary (HLWATIKA; BHAT, 2002; CASSON; HETHERINGTON, 2010). According to several authors (CUTLER; BRANDHAM, 1977; BARTHLOTT, 1981; MASLE et al., 2005), a number of morphological attributes, especially epidermal ones, are genetically determined (i.e., they are not dependent on environmental influence). These characteristics are preferred when taxonomic classifications are under consideration, since they are constant and specific to each group.

Furthermore, it is also worth noting that in our paper some characteristics used to differentiate species have never been published or are poorly explored for taxonomic purposes. For instance, several authors regard stomata as labile structures that are highly influenced by environmental variables (WILKINSON, 1979; EHONEN et al., 2017). Nonetheless, this variation has been shown to be predominantly quantitative. According to Sinclair (1990), the number of stomata present in a leaf per unit area is related to drought resistance, since the density of the stomata increases or decreases according to water stress. On the other hand, the shape of stomata guard cells seems to be under strong genetic control and is only slightly influenced by current climatic factors (SINCLAIR, 1990). Consequently, the use of stomata shape as a taxonomic marker is reasonable. In addition, in order to increase the reliability of the method, we also considered the elevation of the stomata relative to the surrounding epidermal cells (i.e., if the stomata are at a higher or lower level compared to the remaining epidermal cells).

This trait, as far as we have researched, has not been considered as a taxonomic marker before. We tested and maintained this character because, although it may be associated with climatic factors (HAWORTH; MCELWAIN, 2008), we found stomata at different levels in several unrelated species (e.g., P. myrtifolia and $C$. americana) that all grow in places with a similar climate. It is well documented that some plants in dry environments may have their stomata in a cavity, putting them at a lower level compared to other epidermal cells (sunken stomata; JORDAN et al., 2008; ADEBOWALE et al., 2014). Nevertheless, we found that most species have stomata at the same level of neighboring cells, even those that inhabit the same environment, such as P. myrtifolia and C. americana. Again, this apparent paradox can be explained by genetic control of the stomata (PETERSON et al., 2010), which reflects an adaptation to the climatic conditions of the place where the plants evolved rather than the current environment.

Another relevant fact is that most of the species analyzed in our study have a visible cuticle on the adaxial leaf surface. According to Withner et al. (1974), a cuticle occurs as an adaptation to direct sun exposure, and the higher the sunlight exposure the thicker the cuticle. In addition, other factors also influence cuticle formation, such as soil, moisture and altitude. (FAHN, 1990; OLIVEIRA; SAJO, 1999). However, recent studies (e.g., ADEBOWALE et al., 2014) suggest that the presence of a cuticle and its distinctive characteristics do not necessarily have such a close correlation with ecological factors, but rather are conditioned by genetic factors.

The shape of the anticlinal epidermal cell walls has been used by several authors as a taxonomic marker (e.g., CEOLIN et al., 2007; ULLAH et al., 2018). Pyykkö (1979) suggested that there is a relationship between 
the sinuosity of anticlinal cell walls and light intensity, arguing that plants with straight walls are located in the upper layer of the forest and those with a sinuous shape inhabit the lower stratum. In our study, we found no correlation between cell shape and luminosity, which differs from Pyykkö's (1979) proposition. For example, in $C$. marginatum (straight contour), $C$. vernalis (sinuous contour) and $C$. americana (sinuous contour), the epidermal cell shape was uniform on both abaxial and adaxial surfaces, regardless of the degree of luminosity to which individuals were subjected. In addition, according to Muntoreanu et al. (2011), species of Pilocarpus usually have anticlinal cell walls with a straight contour, regardless of climatic factors. Thus, it is possible to conclude, once again, that the shape variation of anticlinal cell walls is not readily related to current climatic conditions, but rather to the genetics of each species, which may have been selected in another climatic context.

Scents and flavors, despite being subjective, should not be neglected as a source of taxonomic characteristics, due to their high value for the identification of some families, such as Lauraceae, Myrtaceae, and Rutaceae (SOBRAL et al., 2006; CEOLIN et al., 2009). Rutaceae are particularly well characterized by the presence of translucent glands in the leaves (observed even with the naked eye), and this attribute is so specific and striking that it is used for family identification of fossilized leaves (PAN, 2010). These glands are saturated with essential oils that exude a characteristic scent when leaves are crushed. In the present study, when analyzing $P$. pennatifolius, it was possible to see the translucent glands in the epidermal print, demonstrating their value for differentiating species, regardless of whether the cell content and aromatic characteristics are not preserved.

According to our results and discussion, we conclude that it is possible to use the micromorphology of the leaf epidermis as a source of taxonomic markers to help identify plant seedlings, since several traits we discuss are known to only vary modestly within each species. In addition, the technique of glue printing was once again shown to be a viable tool to replace traditional plant anatomy practices, since it is fast, inexpensive, efficient, and makes it possible to view anatomical differences among species.

\section{References}

ADEBOWALE, A.; NAIDOO, Y.; LAMB, J.; NICHOLAS, A. Comparative foliar epidermal micromorphology of Southern African Strychnos L. (Loganiaceae): taxonomic, ecological and cytological considerations. Plant Systematics and Evolution, Heidelberg, v. 300, n. 1, p. 127-138, 2014.

ALVES, M. V.; ESTELITA, M. E. M.; WANDERLEY, M. G. L.; THOMAS, W. W. Aplicações taxonômicas da anatomia foliar das espécies brasileiras de Hypolythrum Rich. (Cyperaceae). Revista Brasileira de Botânica, São Paulo, v. 25, n. 1, p. 1-9, 2002.

ANDERSON, L. C.; CREECH, J. B. Comparative leaf anatomy of Solidago and related Asteraceae. American Journal of Botany, St. Louis, v. 62, n. 5, p. 486-493, 1975.

BARTHLOTT, W. Epidermal and seed surface characters of plants: systematic applicability and some evolutionary aspects. Nordic Journal of Botany, Lund, v. 1, n. 1, p. 345-355, 1981.

BIERAS, A. C.; SAJO, M. G. Anatomia foliar de Erythroxylum P. Browne (Erythroxylaceae) do cerrado do estado de São Paulo, Brasil. Acta Botanica Brasilica, Belo Horizonte, v. 18, n. 3, p. 601-612, 2004.

CARVALHO, J. O. P. Análise estrutural da regeneração natural em floresta tropical densa na região do Tapajós no estado do Pará. 1982.128 f. Dissertação (Mestrado em Ciências Florestais) Universidade Federal do Paraná, Curitiba. 1982.

CASSON, A. S.; HETHERINGTON, A. M. Environmental regulation of stomatal development. Current Opinion in Plant Biology, London, v. 13, n. 1, p. 90-95, 2010.

CEOLIN, G. B.; ROSITO, J. M.; CANTO-DOROW, T. S. Leaf surface characters applied to Lauraceae taxonomy in a seasonal forest of Southern Brazil. Brazilian Archives of Biology and Techology, Curitiba, v. 52, n. 6, p. 1453-1460, 2009.

CEOLIN, G. B.; RÜCKER, A.; KRAY, J. G. Análise epidérmica foliar na diferenciação de plântulas de Geonoma schottiana e Euterpe edulis (Arecaceae). Revista Brasileira de Biociências, Porto Alegre, v. 5, n. S2, p. 18-20, 2007.

CUTLER, D. F.; BRANDHAM, P. E. Experimental evidence for the genetic control of leaf surface in hybrid Aloineae (Liliaceae). Kew Bulletin, Kew, v. 32, n. 1, p. 23-32, 1977.

EHONEN, S.; YARMOLINSKY, D.; KOLLIST, H.; KANGASJÄRVI, J. Reactive Oxygen Species, Photosynthesis, and Environment in the Regulation of stomata. Antioxidants \& Redox Signaling, New York, v. 30, n. 9, p. 1220-1237, 2017.

ESAU, K. Plant anatomy. 2. ed. Tokyo: Toppan Press, 1960. 768 p. FAHN, A. 1982. Plant anatomy. Oxford: Pergamon Press, 1982. $576 \mathrm{p}$.

FAHN, A. 1990. Plant anatomy. 4. ed. Oxford: Pergamon Press. $600 \mathrm{p}$.

GAMA, J. R. V.; BOTELHO, S. A.; BENTES-GAMA, M. M.; SCOLFORO, J. R. S. Estrutura e potencial futuro de utilização da regeneração natural de floresta de várzea alta no município de Afuá, 
estado do Pará. Ciência Florestal, Santa Maria, v. 13, n. 2, p. 71 82, 2003.

GUANTAY, M. E.; TERÁN, M. H. Estudio morfo-anatómico de las espécies del género Elaphoglossum Schott de Tucumán. Lilloa, Tucumán, v. 38, n. 1, p. 73-84, 1995.

HAWORTH, M.; MCELWAIN, J. Hot, dry, wet, cold or toxic? Revisiting the ecological significance of leaf and cuticular micromorphology. Paleogeography, Paleoclimatology, Paleoecology, Amsterdam, v. 262, n. 1, p. 79-90, 2008.

HICKEY, M.; KING, C. The Cambridge illustrated glossary of botanical terms. Cambridge: Cambridge University Press, 2000. $222 \mathrm{p}$.

HLWATIKA, C. N. M.; BHAT, R. B. An ecological interpretation of the difference in leaf anatomy and its plasticity in contrasting tree species in Orange Kloof, Table Mountain, South Africa. Annals of Botany, Oxford, v. 89, n. 1, p. 109-114, 2002.

JIMENEZ-SAA, H. Um método para facilitar el aprendizaje de la dendrologia tropical. Turrialba, San José, v. 19, n. 1, p. 109-116, 1969.

JORDAN, G. J.; WESTON, P. H.; CARPENTER, R. J.; DILLON, R. A.; BRODRIBB, T. J. The evolutionary relations of sunken, covered, and encrypted stomata to dry habitats in Proteaceae. American Journal of Botany, St. Louis, v. 95, n. 5, p. 521-530, 2008.

MASLE, J.; GILMORE, S. R.; FARQUHAR, G. D. The ERECTA gene regulates plant transpiration efficiency in Arabidopsis. Nature, London, v. 436, n. 7052, p. 866, 2005.

MUNTOREANU, T. G.; SILVA-CRUZ, R.; MELO-DE-PINNA, G. F. Comparative leaf anatomy and morphology of some neotropical Rutaceae: Pilocarpus Vahl and related genera. Plant Systematics and Evolution, Heidelberg, v. 296, n. 1-2, p. 87-99, 2011.

OLIVEIRA, V. C.; SAJO, M. G. Anatomia foliar de espécies epífitas de Orchidaceae. Revista Brasileira de Botânica, São Paulo, v. 22, n. 3, p. 365-374, 1999.

PAN, A. D. Rutaceae leaf fossils from the Late Oligocene (27.23 Ma) Guang River flora of northwestern Ethiopia. Review of Palaeobotany and Palynology, Amsterdam, v. 159, n. 3, p. 188194, 2010.

PETERSON, K. M.; RYCHEL, A. L.; TORII, K. U. Out of the mouths of plants: the molecular basis of the evolution and diversity of stomatal development. The Plant Cell, Waterbury, v. 22, n. 2, p. 296-306, 2010.
PRYCHID, C. J.; RUDALL, P. J. Calcium oxalate crystals in monocotyledons: a review of their structure and systematic. Annals of Botany, Oxford, v. 84, n. 6, p. 725-739, 1999.

PYYKKÖ, M. Morphology and anatomy of leaves from some woody plants in a humid tropical forest of Venezuelan Guayana. Acta Botanica Fennica, Helsinki, v. 112, p. 1-41, 1979.

RODERJAN, C. V. Morfologia do estágio juvenil de 24 espécies arbóreas de uma floresta com araucária. 1983. 148 f. Dissertação (Mestrado em Ciências Florestais) - Universidade Federal do Paraná, Curitiba. 1983.

SEGATTO, F. B.; BISOGNIN, D. A.; BENEDETTI, M.; COSTA, L. C.; RAMPELOTTO, M. V; NICOLOSO, F. T. Técnica para o estudo da anatomia da epiderme foliar de batata. Ciência Rural, Santa Maria, v. 34, n. 5, p. 1597-1601, 2004.

SINCLAIR, R. Water relations in orchids. In: ARDITTI, J. (Ed.). Orchid biology: reviews and perspectives. London: Cornell University Press, 1990. p. 100-119.

SOBRAL, M.; JARENKOW, J. A.; BRACK, P.; IRGANG, B. E.; LAROCCA, J.; RODRIGUES, R. S. Flora arbórea e arborescente do Rio Grande do Sul, Brasil. Porto Alegre: Rima Novo Ambiente, 2006. 358 p.

ULLAH, F.; ZAFAR, M.; AMHAD, M.; SULTANA, S.; ULLAH, A.; SHAH, S. N.; BUTT, A. M.; MIR, S. Taxonomic implications of foliar epidermal characteristics in subfamily Alsinoideae (Caryophyllaceae). Flora, Jena, v. 242, p. 31-44, 2018.

WILKINSON, H.P. The plant surface (mainly leaf). In: METCALFE, C. R.; CHALK, L. (Ed.). Anatomy of the Dicotyledons. Oxford: Clarendon Press, 1979. p. 97-165.

WITHNER, C. L.; NELSON, P. K.; WEJKSNORA, P. J. The anatomy of orchids. In: WITHER, C. L. (Ed.). The orchids cientific studies. New York: John Wiley \& Sons Press, 1974. p. 267-334.

WOODENBERG, W.; GOVENDER, J.; MURUGAN, N.; RAMDHANI, S. Cycad forensics: leaflet micromorphology as a taxonomic tool for South African cycads. Plant Systematics and Evolution, Heidelberg, v. 305, n. 6, p. 445-457, 2019.

ZHONG, M.; SHAO, X.; WU, R.; WEI, X.; van LOGTESTIJN, R. S.; CORNELISSEN, J. H. Contrasting altitudinal trends in leaf anatomy between three dominant species in an alpine meadow. Australian Journal of Botany, Collingwood, v. 66, n. 5, p. 448$458,2018$. 